\title{
Susceptibility of locally cultivated groundnut (Arachis hypogaea) varieties to aflatoxin accumulation in Homa Bay County, Kenya
}

\author{
Ndisio Boaz*, Peter Wachira, Victor Kagot and Sheila Okoth \\ School of Biological Sciences, University of Nairobi, Chiromo P. O. Box 30197, GPO, Nairobi, Kenya.
}

Received 29 May, 2017; Accepted 14 July, 2017

\begin{abstract}
Groundnut is one of the staple foods in many parts of the world. Due to its high nutrient content, the nuts are liable to colonization by aflatoxigenic fungi and subsequent aflatoxin accumulation. This study was aimed at determining susceptibility of locally grown groundnut varieties to Aspergillus flavus in Homa Bay County, Western Kenya. A pretested questionnaire was used to survey agronomic practices on groundnut cultivation in 75 randomly selected households in the study site. From each household farm, $100 \mathrm{~g}$ soil samples and $500 \mathrm{~g}$ of groundnuts were collected at harvest and $A$. flavus isolated on Modified Rose-Bengal Agar and identified. Aflatoxin was then extracted from each of the groundnut samples and quantified using direct competitive enzyme linked immunosorbent assay (ELISA). Red Valencia was the most cultivated among the 8 varieties identified. Farmers (66\%) obtained the planting seeds from the local market and most (92\%) did not use fertilizers with majority (94\%) having no knowledge of aflatoxins. There was no significant inter-variety difference in aflatoxin accumulation $(p=0.744, F=0.581, D f=6,61)$. A highly significant association $(t=2.652 ; P=0.010)$ was found between storage state of the groundnuts and aflatoxin levels, with $94 \%$ of the samples stored unshelled having aflatoxin levels below $10 \mathrm{ppb}$. Overall, only $6.7 \%$ of kernels sampled from all the divisions did not meet the EC aflatoxin limit of $\leq 4 \mathrm{ppb}$ while $4 \%$ did not meet the KEBS limit of $\leq 10 \mathrm{ppb}$. Though the agronomic practices were poor, aflatoxin levels were predominantly low in the region suggesting that the aflatoxin accumulation is likely influenced by agro-ecological zoning as other studies have also been indicated.
\end{abstract}

Key words: Groundnuts, Aflatoxins, Aspergillus flavus.

\section{INTRODUCTION}

In Kenya, there is a heavy consumption of groundnuts as vegetables, in weaning formulas and as snacks. This is the case in the developing world where approximately five billion people are at risk of chronic exposure to mycotoxins through consumption of maize and groundnuts contaminated with aflatoxin (Wagacha et al., 2013). This report indicate that aflatoxin levels in groundnuts in Kenya, range from 0 to 7525 ppb, and this

${ }^{*}$ Corresponding author: E-mail: otienondisio@yahoo.com. Tel: +254(0) 714867387.

Author(s) agree that this article remains permanently open access under the terms of the Creative Commons Attribution License 4.0 International License 
puts the people in the region at risk of aflatoxicosis (Mutegi et al., 2009).

Studies by various researchers have indicated that there is human exposure to aflatoxins in Western Kenya. Firstly, the region has been reported to have high levels of stunting in children a trait attributed to consumption of small quantities of aflatoxin over a long period of time (Bhat and Vasanthi, 2003; Okoth and Ohingo, 2005; Mutegi et al., 2009). Secondly, groundnuts are mainly produced by resource-limited farmers characterized by poor planting, harvesting, drying, processing and storage methods, factors linked to fungal contamination and aflatoxin accumulation in groundnuts (Waliyar et al., 2005).

Due to heavy consumption of groundnuts in the region both by adults and children; a large proportion of the population are likely to be exposed to aflatoxins (Okoth and Ohingo, 2005). It is difficult to completely eliminate aflatoxins from food once they are produced (Okello et al., 2010). Mitigation methods are therefore focused on controlling fungal contamination. One of the susceptibility factors is groundnut variety. Currently, there is no well known locally cultivated groundnut variety that shows resistance to fungal colonization and aflatoxin accumulation and a set of agronomic practices which has been accepted and integrated by farmers in Homa bay County. Therefore, there is an urgent need to study and identify a locally grown variety that shows low susceptibility to aflatoxin accumulation. There is also need to identify acceptable and easy to use technologies and pre- and post-harvest agricultural activities which can be applied by the farmers in the study area so as to combat the aflatoxin menace and alleviate the impending health catastrophe should the entire population be exposed to the aflatoxins.

\section{MATERIALS AND METHODS}

Homa Bay County is located in South Western Kenya along Lake Victoria. Agro-ecological zones where groundnuts are grown are the lower midland zone 4 (LM4) and lower midland zone 3 (LM3) (Figure 1). Temperatures range from 17.1 to $34.8^{\circ} \mathrm{C}$, with rainfall amounts of between 250 and $700 \mathrm{~mm}$ per annum (About Homa Bay County in Kenya, 2017). Agriculture is a major contributor to household income (52\%) and groundnut is a major cash crop alongside sugarcane and rice (About Homa Bay County in Kenya, 2017). Average farm sizes in the county is small with an average of 2.0 ha. While groundnut is grown under smallholder farming, sugar cane is cultivated at a large scale (About Homa Bay County in Kenya, 2017)

Seventy five households were randomly picked using Geographical information system (GIS) mapping (a system designed to capture, store, manipulate, analyze, manage, and present spatial or geographic data) followed by confirmation and adjustments on the actual ground to the nearest household.

Each household was interviewed using a pre-tested questionnaire developed after conducting focus group discussions involving 20 participants from Homa Bay County. The data collected included: Pre-harvest practices such as farm preparation, the source of groundnut seeds, planting practices soil amendments/fertilizers, weed control, pest control, maturity checks, harvest methodology and post-harvest practices such as drying, storage, shelling, value addition (processing to peanut butter), market and general knowledge on aflatoxins. From each household, $500 \mathrm{~g}$ of groundnuts was sampled at the top, center and bottom of each bag in storage. Soil from each farm was sampled, so as to isolate $A$. flavus from the soil. Top soil was augured at a depth of $0-25 \mathrm{~cm}$ and half a kilogram of soil collected. Five samples were taken from each farm at random and then be mixed to form a composite sample representative of the farm.

Fungi were isolated from the soil samples and groundnuts using the dilution plating technique on a Modified dicloran rose Bengal agar (MDRB) (Probst et al., 2007). The number Aspergillus sp. in each sample was expressed as the number of colony forming units (CFUs) per gram of sample (Jaime-Garcia and Cotty, 2004). CFUs/g was calculated as follows:

Number fungi per gram of sample $=\frac{\text { No. of colonies }}{\text { Amount plated } x \text { dilution factor }}$

\section{Identification of Aspergillus species}

Aspergillus sp. were distinguished macroscopically based on colony diameter, exudates and soluble pigment, surface and reverse colors and texture, shape, margins, elevation, pigmentation, the pattern of growth and conidial morphology characteristics (Klich, 2002). Microscopic examination of Aspergillus sp. was done and identification done according to taxonomic schemes proposed by Klich and Pitt (1988) and Pitt and Hocking (1985).

In order to determine the aflatoxigenicity of the isolated and identified species, DNA extraction was done using ZR Fungal/Bacterial DNA MiniPrepTM (Zymo Research) kit according to manufacturer's instructions. PCR amplifications were performed in $25 \mu \mathrm{l}$ of a reaction mixture containing $12.5 \mu \mathrm{l}$ One Taq $2 x$ Mastermix with standard buffer (New England BioLabs), $1 \mu$ of each primer, $8.5 \mu \mathrm{l}$ Nuclease-free (double-distilled) water and $2 \mu \mathrm{l}$ of the template DNA. PCR was carried out as follows: 1 step at $94^{\circ} \mathrm{C}$ for $5 \mathrm{~min} ; 40$ cycles of the following three steps: $20 \mathrm{~s} 94^{\circ} \mathrm{C}, 20$ $s$ at annealing temperature of $57^{\circ} \mathrm{C}, 1 \mathrm{~min} 72^{\circ} \mathrm{C}$; and one final 30 min step at $72^{\circ} \mathrm{C}$. PCR products were separated by electrophoresis on a $1 \%$ agarose gel with $2 \mu \mathrm{l}$ ethidium bromide in $1 \times$ TBE buffer and visualized under UV light.

\section{Determination of levels of aflatoxin in groundnuts}

The groundnut samples were analyzed for total aflatoxin with a direct competitive ELISA using Total Aflatoxin Assay- Low matrix kit (Helica Biosystems Inc.) according to the manufacturer's instruction. (www.helica.com/assets/Total_Aflatoxin_low_matrix_-96.pdf).

\section{Statistical analysis}

Analysis of Variance (ANOVA) was performed to determine the frequency of isolation of different strains of $A$. flavus and $A$. parasiticus. Determination of the relationship between toxigenic strains and toxin production was carried out using Pearsons correlation analysis.

To determine the relationship between the amounts of aflatoxin found in the groundnut kennels, the Aspergillus species isolated from the same kennels and the respective agronomic activities carried out by the farmers from whom the samples were collected, The samples were grouped into three categories based on their aflatoxin content in regard to established economic limits used in imposing trade restrictions by Kenya bureau of standards (KEBS) and European Union (EU). The proportion of the samples in each category was calculated. The samples were grouped as follows; 


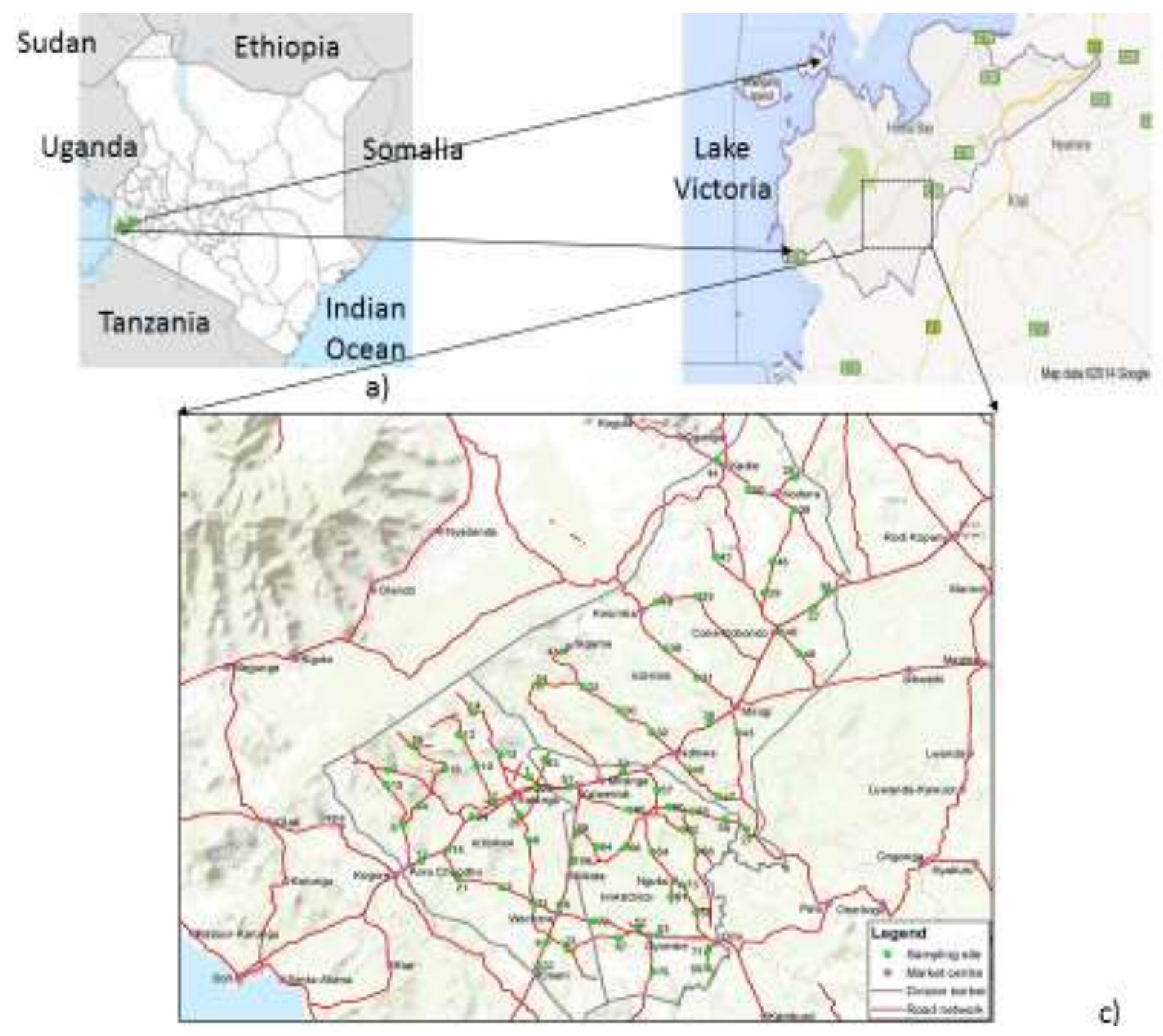

Figure 1. Map showing the study area; (a) Map of Kenya showing the location of Homa Bay County (in green), (b) Homa Bay County showing the enclosed study area, (c) the sampling points.

samples with $<4 \mathrm{ppb}$ (acceptable by both KEBS and EU); $\geq 4 \mathrm{ppb}$ to $\leq 10 \mathrm{ppb}$ (rejected by EA but acceptable under KEBS standards), and $>10 \mathrm{ppb}$. (Rejected by both EU and KEBS) (Wu and Guclu, 2012); Categorical data analysis using contingency tables was used to evaluate the association between these aflatoxin categories and fungal populations and agronomic activities. Categorical data analyses (Stokes et al., 2009) were carried out using R Gui version 3.3.2.

\section{RESULTS}

\section{Common groundnut varieties}

Among the eight groundnut varieties identified ICG-9991 was the most dominant. The levels of aflatoxin ranged from 0 to $43.23 \mathrm{ppb}$. Overall, $93.3 \%$ of the samples had aflatoxin levels below both KEBS and EC standards. This shows that majority of the nut produced are within the safe limits for consumption. No variety showed resistance to aflatoxin accumulation ( $\mathrm{P}$-value $=0.744, \mathrm{~F}=0.581, \mathrm{Df}=6$, $61)$.

\section{Agronomic activities}

A large proportion of farmers (66\%) bought seeds from local markets. The remaining proportion either recycling the previous seasons harvest or purchased from Agroshops. Majority of the farmers (92.1\%) did not use fertilizer while growing groundnuts, of the ones that did $85.7 \%$ used organic manure which was applied a few weeks before planting. In majority of the farms (77.8\%), weeding was done twice, just after emergence and just before pegging. Majority of the farmers $(70.9 \%)$ used the browning of the leaves to tell if groundnuts were ready for harvesting, others $(25.3 \%)$ did random checks by digging 


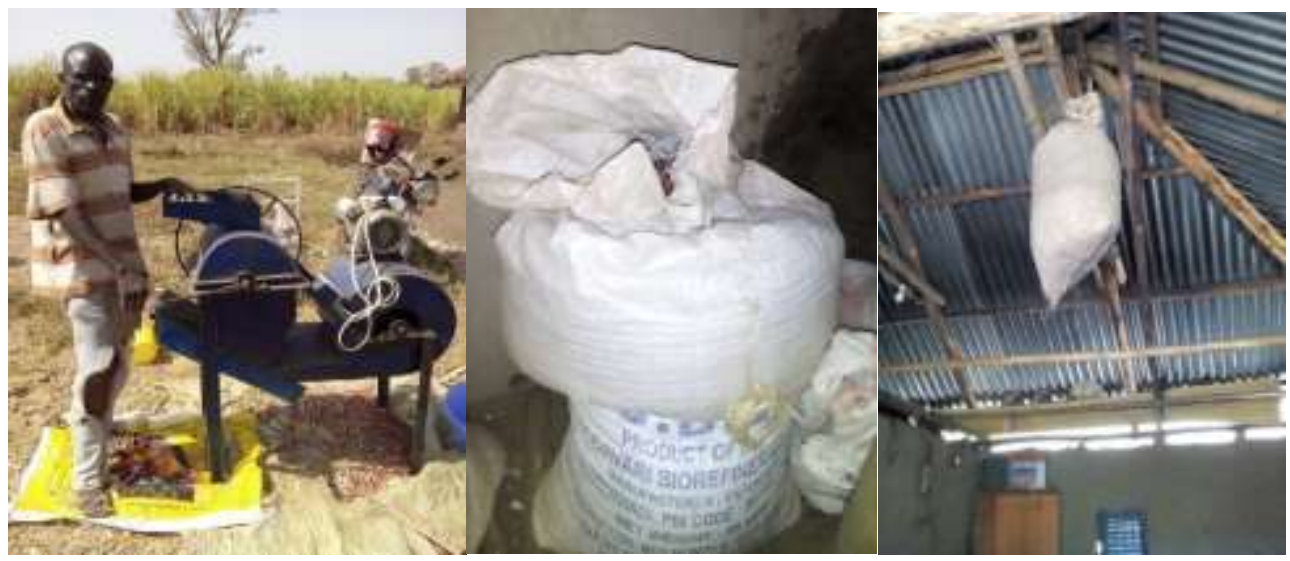

Figure 2. A farmer operating a manually operated groundnut sheller with electric motor and storage containers and place in Homa Bay County.

Table 1. Proportion (\%) of farmers practicing different cropping systems and applying soil amendments in Ndhiwa, Kobama and Nyarongi division, Homa Bay County.

\begin{tabular}{lcccc}
\hline \multirow{2}{*}{ Division } & \multicolumn{4}{c}{ Cropping systems } \\
\cline { 2 - 5 } & Mixed cropping & Mono cropping & Crop rotation & Application of soil amendments \\
\hline Ndhiwa & 100.0 & 0.0 & 20.0 & 4.0 \\
Kobama & 92.0 & 8.0 & 40.0 & 12.0 \\
Nyarongi & 96.0 & 4.0 & 36.0 & 28.0 \\
Mean & 96.0 & 4.0 & 32.0 & 14.7 \\
\hline
\end{tabular}

up randomly plants in the farm and checking the nuts had hardened enough. In most of the farms (78\%), harvesting was done by digging up the plants using hand held hoes. No mechanized method of harvesting was observed in the study area. Drying was done in most cases for 3 to 4 days and most farmers tested the dryness in the nuts by the popping sound produced as they cracked the pods (Figure 2).

The nuts were kept in the pods and shelling was only done prior to sale. Storage was in polypropylene bags kept on the floor, raised a few inches up by a rack made of wood. Majority (92.9\%) of the population surveyed had no knowledge on aflatoxin contamination on groundnuts hence they neither knew nor carried out any control measure towards aflatoxin contamination on groundnuts pre- and post-harvest. Of the remaining $7.1 \%$, the knowledge on aflatoxin was quite shallow with only two individuals had a clear knowledge on agronomic practices that could be put in place to reduce aflatoxin contamination in groundnuts. Other agronomic practices carried out in the study area in each of the three divisions were as in the proportions given in Table 1.

A highly significant association ( $t=2.652 ; p=0.010)$ was found between storage state of the groundnuts and aflatoxin levels with $94 \%$ of samples stored in the unshelled state having aflatoxin levels below $10 \mathrm{ppb}$ in comparison wiith $84 \%$ of samples stored after being shelled (Table 2).

No significant association was detected between levels of aflatoxin and land under production, whether or not the crops were intercropped; use of fertilizers, weeding frequency, application of crop rotation, disease and pest control, cultivar type, harvest method or drying duration.

\section{Population of A. flavus in the study area}

Various Aspergillus sp. were isolated from the soil sampled from Homa Bay County from the soil. The species included Aspergillus flavus S-strain, Aspergillus flavus L-strain, Aspergillus niger, Aspergillus parasiticus and Aspergillus ochraecious (Table 3).

There was no significant $(p \geq 0.05)$ variation in the population of the species in the soil sampled from the different regions in Homa Bay County except for $A$. parasiticus, which was isolated in the highest incidence with a mean population of $2160 \mathrm{CFU} / \mathrm{g}$ soil (Table 2). The highest mean population (1780 CFU/g soil) of $A$. flavus Sstrain was in soil sampled from Nyarongi region while the population of $A$. flavus L-strain was highest (240 CFU/g soil) in soil sampled from Ndhiwa division.

There was no correlation between $A$. flavus $S$ and $\mathrm{L}$ 
Table 2. Correlation between different agronomic practices and aflatoxin levels found in the groundnuts sampled from various farmers in Homa Bay County.

\begin{tabular}{llcccc}
\hline Agronomic practices & Std. error & $\mathbf{t}$ value & $\operatorname{Pr}(>|\mathbf{t}|)$ & Significance \\
\hline \multirow{5}{*}{ Pre-harvest } & 9.5947 & -0.813 & 0.4192 & $\mathrm{Ns}$ \\
& (Intercept) & 0.7156 & -0.141 & 0.888 & $\mathrm{Ns}$ \\
& Land under production & 3.6565 & 0.044 & 0.965 & $\mathrm{Ns}$ \\
& Whether or not intercropping was done & 1.5866 & 0.6 & 0.551 & $\mathrm{Ns}$ \\
& Crop rotation & 1.3943 & 0.64 & 0.5244 & $\mathrm{Ns}$ \\
& Plant residue handling & 0.72 & -1.328 & 0.1892 & $\mathrm{Ns}$ \\
& Seed source & 1.4579 & 1.167 & 0.2476 & $\mathrm{Ns}$ \\
& Cultivar type & 2.0739 & -1.208 & 0.2316 & $\mathrm{Ns}$ \\
& Fertilizer application & 1.4216 & -1.567 & 0.1222 & $\mathrm{Ns}$ \\
& Weeding frequency & 1.4643 & -0.108 & 0.914 & $\mathrm{Ns}$ \\
& Pest and disease management & 1.5118 & 2.026 & 0.0472 & $*$ \\
& Drought problem & 1.5563 & 1.601 & 0.1146 & $\mathrm{Ns}$ \\
& Harvesting methodology & 1.4246 & -0.176 & 0.8608 & $\mathrm{Ns}$ \\
& Drying duration & 2.4478 & 2.652 & 0.0102 & $*$ \\
\hline
\end{tabular}

Dispersion parameter for Gaussian family taken to be 33.22585; Null deviance: 2538.7 on 74 degrees of freedom; Residual deviance: 2026.8 on 61 degrees of freedom (AIC: 490.09).

Table 3. Population (CFU/g of soil or groundnut) of various Aspergillus sp. in soil and groundnut samples from various farms in Homa Bay County at harvest in June 2015.

\begin{tabular}{lcc}
\hline \multirow{2}{*}{ Isolate } & \multicolumn{2}{c}{ Mean \pm SE } \\
\cline { 2 - 3 } & Soil & Nuts \\
\hline A. flavus L strain & $213 \pm 54.7$ & $306.6 \pm 100.4$ \\
A. flavus S strain & $1133 \pm 338.0$ & $206.6 \pm 44.6$ \\
A.Parasiticus & $920 \pm 573.7$ & $1393.3 \pm 169.67$ \\
\hline
\end{tabular}

Table 4. Correlation of the occurrence of various Aspergillus species isolated from various farms in Homa bay County.

\begin{tabular}{lccccc}
\hline & A. flavus L-strain & A. flavus S-strain & A. niger & A. ochraecious & A. parasiticus \\
\hline A. flavus L-strain & 1.000 & & & & \\
A. flavus S-strain & $-0.0906^{\mathrm{ns}}$ & 1.000 & & & \\
A. niger & $-0.0639^{\mathrm{ns}}$ & $0.0665^{\mathrm{ns}}$ & 1.000 & & \\
A. ochraecious & $-0.0580^{\mathrm{ns}}$ & $-0.0448^{\mathrm{ns}}$ & $-0.0766^{\mathrm{ns}}$ & 1.000 & \\
A. parasiticus & $0.0206^{\mathrm{ns}}$ & $-0.1094^{\mathrm{ns}}$ & $-0.07876^{\mathrm{ns}}$ & $-0.1214^{\mathrm{ns}}$ & 1.000 \\
\hline
\end{tabular}

strains. There was also a negative correlation between the fungal populations of the $A$. flavus $L$ and $S$ strains and $A$. niger and a positive correlation between the fungal populations of $A$. ochraecious and $A$. parasiticus but in both cases the correlation was insignificant (Table 4).

\section{DISCUSSION}

Eight varieties were identified in this study as Homa Bay local, ICGV-9991, ICGV-12991, Red Valencia, CG07,
CG2, CG3, and SM99568. Over 14 groundnut varieties are known to be grown in western Kenya these include Red Valencia. Minipinta, Bukene, Serere 116, Makulu red, Atika, Asyria Mwitunde,, Texas Groundnut, ICGV-07, ICGV-12988, ICGV-12991, Homabay local, Cianda and SM99508 (C-MAD, 2011; Gitau, 2017), with other varieties such as ICGV90708 (Valencia type) grown in other parts of Kenya, particularly in Rift valley region. Most of the varieties identified are in agreement with the types documented to be in the area already apart from CG2, CG3, and SM99568. Not all varieties documented 
were found in this area most probably because of the sample size and the season. Some varieties are preferred over the others in the first season (March to July). The choice of variety also relies heavily on the end use and market demand. Varieties with larger kennels are light colored preferred for making peanut butter or consumed as boiled nuts while the red and smaller varieties are preferred for roasted groundnuts. The varieties planted at higher frequency/in larger volumes were CG7, Red Valencia, ICG-9991 and Homa-bay local. The Homa Bay local and CG07 have large kennels and are predominantly used for making peanut butter or consumed boiled. The red Valencia and ICG-9991 are small and red are preferred roasted.

Most farmers at Kobama, Ndhiwa and Nyarongi divisions in Homa Bay County produce groundnuts on small scale basis. These individuals do not use contemporary production techniques in their farming practices but rather capitalize on the traditional crop production systems. This may be because of inadequate resources hence little investments into the farms by these farmers. They neither use pesticides and insecticides nor practice any recommended soil amendment methods developed for groundnut production. Instead, most of these farmers, about $90 \%$ of farms, engage in mixed cropping, with maize being the primary crop with groundnuts as the secondary crop. Even for farmers who practiced crop rotation in their activities, groundnut production alternates with the maize crops. This is in agreement with a study conducted by Kumar and Popat (2010). Farmers with extensive farming lands are inclined to adopt efficient aflatoxin management strategies compared to those with small farming areas.

According to $\mathrm{Wu}$ and Khlangwiset (2010), crops such as groundnuts and maize have a high susceptibility to aflatoxigenic fungi like Aspergillus sp, explaining the high incidence of the particular species of fungi within the study area. As most farmers use maize in the mixed farming practices and rotation processes, fungi resurgence remains inevitable. Besides, studies conducted in the USA provided a high concentration of $A$. flavus propagules in soils collected from maize fields compared to these from wheat and cotton farms (Abbas et al., 2004; Reddy and Raghavender, 2007). A study conducted by Griffin et al. (1981) upholds these findings by providing the existence of a greater concentration of A. flavus in soils with continual maize and groundnut production within the same fields.

The population of aflatoxigenic fungal species was found to be high in the majority of the farms with maize being the previous crop and farmers doing no crop rotation whatsoever. The results of the study concur with the findings by Jaime-Garcia and Cotty (2010). According to these scholars, the previous crop plays a significant role in determining the incidence of both the A. flavus and $A$. flavus S-strains of the fungi. Such findings suggest the to lower the prevalence of aflatoxin contamination in groundnut production. A study conducted by Mutegi et al. (2012) in Western Kenya indicated that the percentage of $A$. flavus and $A$. parasiticus isolates testing for aflatoxin B1 and B2 was significantly higher in samples obtained from farmers who did not practice crop rotation compared to those that rotated their crops. Therefore, as Strosnider et al. (2006) contemplate, useful introduction and implementation of rotational programs help to break the life cycle of aflatoxin-producing pathogens

Despite the fact that most farmers in the study exhibited poor agronomic practices, aflatoxin levels were relatively low agreeing with the findings of Mutegi et al. (2009) that in addition to agronomic practice, the agroecological zone also influences the aflatoxin accumulation. For example Eastern Kenya will always have high aflatoxin levels in comparison to Western Kenya and or the North Rift region of Kenya. Other factors which might have led to the low toxin incidence include; application of lime and farm yard manure as soil amendments. These, have proved effective in reducing A. flavus contamination and aflatoxin levels by 50 to $90 \%$ (Waliyar et al., 2008). Lime contains calcium which tends to thicken the cell wall and accelerate pod filling. On the other hand, manure accentuates the growth of saprophytic microorganisms known to suppress pathogenic fungi in soil. Further, as Reddy et al. (2003) contends, amendments like gypsum provide sufficient calcium to the plant and increase plant tolerance to infections by $A$. flavus. Despite the fact that Aspergillus population does not correlate to aflatoxin accumulation, the Aspergillus populations could have been much lower if the farmer would have considered the use of soil amendments.

The results of the study presented a significant variation in the occurrence and spread of the fungi in groundnut family within the regions of study. Groundnuts grown in Ndhiwa area showed high susceptibility to foliar diseases, particularly early blight, and late blight. Even with the occurrence of the aforementioned diseases, the farmers did not use fungicides as management strategies. As postulated by Hell et al. (2000), smallholder groundnut farming in Western Kenya is typical with disease and pest infestation when meager investments are placed in disease alleviation processes including application of pesticides. According to Mutegi et al. (2009), smallholder farmers do not use pesticides or fertilizers in groundnut production. Moreover, they disregard appropriate agricultural and post-harvest handling practices, which tend to influence aflatoxin concentration.

In concluding the analysis of the study, it is evident that groundnut farmers within the study areas had no knowledge of aflatoxin, hence, did not view its existence as a challenge to their production processes. As Kumar and Popat (2010) stipulates, lack of awareness contributes to high aflatoxin quantities, as detected in some farms in Kobama, Ndhiwa and Nyarongi regions. 
The farmers were unaware of the recommended practices thus their incapability to control aflatoxin contamination in groundnuts.

\section{Population of Aspergillus species and aflatoxin contamination in groundnut kernels}

Four strains of Aspergillus sp were isolated in the study from groundnut kernel samples from the three divisions. These included $A$. flavus L-strain, $A$. flavus S-strain, $A$. parasiticus and $A$. niger. Similar findings were recorded by Mutegi et al. (2012), who isolated members of Aspergillus section Flavi from groundnut kernels in Busia and Homa Bay districts of western Kenya. According to Mutegi, the four strains of Aspergillus sp. are the most predominant species of the fungi in the Western section of the country ( $>60 \%$ incidence rate). From the findings of the study, $69 \%$ of the sampled groundnuts had different strains of Aspergillus section including A. flavus $\mathrm{L}$ strain, $A$. flavus $\mathrm{S}$ strain, $A$. parasiticus, A. tamarii, $A$. caelatus, $A$. alliaceus and $A$. niger.

Arguably, the high population of Aspergillus sp. recorded at the harvest stage may have predisposed the kernels to high aflatoxin contamination. Increased incidence may have occurred as a result of pest attacks or mechanical damages imposed on the kernels during harvesting. Such occurrences introduce channels for the spread and colonization of aflatoxin-producing fungi (Waliyar et al., 2008). Also, poor storage practices affect the levels of aflatoxin concentration, evidenced by the high population of $A$. flavus $\mathrm{S}$-strain and $A$. flavus Lstains in groundnuts accessed from farmer stores. Good groundnut storage practices recommend the use of properly ventilated storage material. However, in the study, $50 \%$ of the farmers stored their groundnuts in polypropylene bags, most of which had poor ventilations to capacitate free flow of air.

The population of $A$. flavus S-strain was found to have no correlation with aflatoxin production In Homa Bay County potentially due to environmental conditions (Mutegi et al., 2009). These findings do not resonate provisions by Wagacha et al. (2013). According to Wagacha et al. (2013), the incidence and population of $A$. flavus S-strain significantly and positively correlate with the levels of total aflatoxin in groundnuts. This may be due to sample size. The presence of $A$. flavus S-strain implies a major health problem to consumers as reports have shown its capability to produce great amounts of aflatoxin especially aflatoxin B1 (Mutegi et al., 2012), also classified as class 1 carcinogen (IARC, 1987). In other studies, Jaime-Garcia and Cotty (2010) reported A. flavus S-strain to be the primary cause of aflatoxin contamination events in Africa and North America.

The current study evaluated aflatoxin levels at harvest in the groundnut samples used across the three divisions in Ndhiwa area. The findings indicated a 93\% compliance with the recommended EU standards of aflatoxin levels $(\leq 4 \mathrm{ppb})$ at harvest. On the other hand, a high proportion of the products (96\%) satisfied the threshold provided by the Kenyan regulatory agency (KEBS), $\leq 10 \mathrm{ppb}$, at harvest. Even though such data indicate high quality and safety levels of the products, the predisposed storage conditions increase the susceptibility of harvested groundnuts to extensive aflatoxin contamination. Farmers in the area used polypropylene and allocated floor sections inside their houses as storage areas.

The study recorded the highest aflatoxin level at 43 ppb. High aflatoxin contamination levels (above the 10 ppb limit set by KEBS) have also been reported in raw and processed groundnuts from different regions in Kenya (Gachomo et al., 2004; Mutegi et al., 2012, 2013; Wagacha et al., 2013). In a recent study Mutegi et al. (2012), 37\% of groundnuts including products like groundnut butter and groundnut flour sampled from Nairobi, Nyanza and Western Kenya failed to meet the 10 ppb total aflatoxin limit set by the Kenya Bureau of Standards (KEBS, 2007). Also, reports by Diop et al. (2000) indicated a mean content of $40 \mathrm{ppb}$ of aflatoxin B1 in over $85 \%$ of groundnut oil sampled in Senegal. Significant concentrations of the toxigenic compounds were also reported in groundnuts sampled from farmers, stockers, traders and processes located Benin. Additionally, studies by Oliveira et al. (2009) conducted in Brazil also reported mean total aflatoxin level of $56 \mathrm{ppb}$ in the sampled unprocessed groundnuts.

\section{Conclusions}

Agronomic practices carried out in Homa Bay County could have no effect on groundnuts infection by Aspergillus species and subsequent contamination by aflatoxins. However, some of the farmers who had aflatoxin contamination on their produce, lacked awareness on key groundnut production practices like proper crop rotation, land preparation methods, common diseases of groundnut and their management. The farmers also did not apply soil amendments or pesticides to control pests and diseases among others. Where crop rotation was practiced, maize was the main crop used in rotation, the maize stalks from the previous season was in most cases left to rot and ploughed back into the farms this type of practice might very likely to lead to accumulation of Aspergillus sp. spores in soil over time leading to rise in cases of fungal infection and aflatoxin accumulation.

This study shows that as much as there are many varieties with different attributes, all are equally vulnerable to aflatoxin contamination both pre- and postharvest, therefore, intervention strategies should be aimed at managing the toxigenic Aspergillus species both pre- and post-harvest. The great diversity of aflatoxin 
producing fungi poses another great risk of aflatoxin contamination in groundnuts.

In as much as there was low aflatoxin contamination of groundnuts sampled from Ndhiwa area, Homa Bay County with most of the samples being within the safe limits set by the EC and KEBS. But with the current production practices in place, there is a great risk of a rapid increase in aflatoxin levels in groundnuts from the area and this will pose a great health concern and may impact negatively on groundnut trade locally, regionally and internationally.

\section{RECOMMENDATIONS}

The awareness on the aflatoxin contamination of groundnuts should be raised, its implications on human and livestock health and trade should be made public information and the farmers trained in depth on possible management strategies. Furthermore, research should be conducted to investigate the different varieties both local landrace and improved types in regard to their resistance to fungal colonization and subsequent aflatoxin contamination.

\section{CONFLICT OF INTERESTS}

The authors have not declared any conflict of interests.

\section{ACKNOWLEDGEMENT}

This study was supported by The University of Nairobi under the MSc scholarship in the School of Biological Science.

\section{REFERENCES}

Abbas HK, Wilkinson, JR Zablotowicz, RM, Accinelli C, Abel CA, Bruns HA, Weaver MA (2004). Ecology of Aspergillus flavus, regulation of aflatoxin production and management strategies to reduce aflatoxin contamination of corn. Toxin Rev. 28:142-153.

About Homa Bay County in Kenya (2017). Kenya-informationguide.com. Retrieved 12 July 2017, from http://www.kenyainformation-guide.com/homa-bay-county.html

Bhat R, Vasanthi S (2003). Mycotoxin food safety risk in developing countries.

Retrievedfrom,http://agris.fao.org/agrisearch/search/display.do?f=201 2/US/US201205600056.xml;US2012205672

C-MAD (2011). Good agronomic practices for Groundnut in Western Kenya, Training manual for Trainers. C-MAD Editorial. www.cmadkenya.org.

Diop Y, Ndiaye B, Diouf A, Fall M., Thiaw C, Thiam A, Barry O, Ciss M, Ba D (2000). Contamination by Aflatoxins of Local Groundnut Oils Prepared in Senegal. Ann. Pharm. Fr. 6:470-474.

Gachomo EW, Mutitu EW, Kotchoni OS (2004). Diversity of fungal species associated with groundnuts in storage and the levels of aflatoxins in infected samples. Intl. J. Agric. Biol. 6:955-959.

Gitau M (2017). Growing Groundnuts in Kenya (Arachis hypogaea). Yagrein.blogspot.co.ke. Retrieved 3 March 2017, from http://yagrein.blogspot.co.ke/2012/11/groundnuts-growing-in-kenyaarachis_5167.html
Griffin GJ, Garren KH, Taylor JD (1981). Influence of crop rotation and minimum tillage on the population of Aspergillus flavus group in groundnut field soil. Plant Dis. 65:898-900.

HelL K, Cardwell KF, Setamou M and Poehling HM (2000). The influence of storage practices on aflatoxin contamination in maize in four agro-ecological zones of Benin, West Africa. J. Stored Prod. Res. 36:365-382.

International Agency for Research on Cancer (IARC) (1987). Overall Evaluation of Carcinogenicity: An Up- dating of IARC Monographs, Report of an IARC Expert Committee, Vol. 1-42, Lyon pp. 83-87.

Jaime-Garcia R, Cotty PJ (2004). Aspergillus flavus in soils and corncobs in south Texas: implications for management of aflatoxins in corn-cotton rotations. Plant Dis. 88:1366-1371.

Jaime-Garcia R, Cotty PJ (2010). Crop rotation and soil temperature influence the community structure of Aspergillus flavus in soil. Soil Biol. Biochem. 42:1842-1847.

Kenya Bureau of Standards (KEBS) (2007). Raw Groundnut for Table Use. Kenya Bureau of Standards Documentation Centre, Nairobi.

Klich MA (2002). Identification of Common Aspergillus Species. Centraalbureau voor Schimmelcultures, Utrecht, The Netherlands. pp. 50-51.

Klich M, Pitt J (1988). Differentiation of Aspergillus flavus from $A$. parasiticus and other closely related species. Transactions of the British Mycological Society 91(1):99-108.

Kumar GD and Popat MN (2010). Factors influencing the adoption of aflatoxin management practices in groundnuts (Arachis hypogaea L.), Intl. J. Pest Manage. 56:165-171.

Mutegi C, Wagacha M, Kimani J, Otieno G, Wanyama R, Hell K, Christie ME (2013). Incidence of aflatoxin in groundnuts (Arachis hypogaea L) from markets in Western, Nyanza and Nairobi Provinces of Kenya and related market traits. J. Stored Prod. Res. 52:118-127.

Mutegi C, Wagacha M, Kimani J, Otieno G, Wanyama R, Hell K, Christie M (2012). Incidence of aflatoxin in groundnuts (Arachis hypogaea L) from markets in Western, Nyanza and Nairobi Provinces of Kenya and related market traits. J. Stored Prod. Res. 52:118-127.

Mutegi CK, Ngugi HK, Hendriks SL, Jones RB (2009). Prevalence and factors associated with aflatoxin contamination of groundnuts from Western Kenya. Intl. J. Food Microbiol. 130(1):27-34.

Okello DK, Kaaya AN, Bisikwa J, Were M, Oloka HK (2010). Management of Aflatoxins in Groundnuts: A manual for Farmers, Processors, Traders and Consumers in Uganda. National Agricultural Research Organization, Entebbe.

Okoth SA, Ohingo M (2005). Dietary Aflatoxin exposure and impaired growth in young children from Kisumu District, Kenya: Cross sectional study. Afr. J. Health Sci. 11(1):43-54.

Oliveira CA, Gonccalves NB, Rosim RE, Fernandes AM (2009). Determination of aflatoxins in groundnut products in the northeast region of São Paulo, Brazil. Intl. J. Mol. Sci. 10(1):174-183.

Pitt J, Hocking A (1985). Interfaces among genera related to Aspergillus and Penicillium. Mycologia 77(5), 810.

Probst C, Njapau H, Cotty PJ (2007). Outbreak of an acute aflatoxicosis in Kenya in 2004: identification of the causal agent. Appl. Environ. Microbiol. 73:2762-2764.

Reddy BN, Raghavender C (2007). Outbreaks of Aflatoxicosis in India. Afr. J. Food Agric. Nutr. Dev. 7:1-15.

Reddy TY, Sulochanamma BN, Subramanyam A, Balaguravaiah D (2003). Influence of weather, dry spells and management practices on aflatoxin contamination in groundnut. Indian Phytopathol. 56(3):262-265.

Stokes M, Davis C, Koch G (2009). Categorical data analysis using the SAS system. New York [u.a.]: Wiley.

Strosnider H, Azziz-Baumgartner E, Banziger M, Bhat RV, Breiman, R, Brune M, Wilson D (2006). Workgroup report: public health strategies for reducing aflatoxin exposure in developing countries. Environ. Health Perspect. 114:1989-1903.

Wagacha, JM, Mutegi C, Karanja L, Kimani J, Christie ME (2013). Fungal species isolated from groundnuts in major Kenyan markets: Emphasis on Aspergillus section Flavi. Crop Prot. 52:1-9.

Waliyar F, Kumar PL, Traore A, Ntare BR, Diarra B and Kodio O (2008). Pre- and Postharvest Management of Aflatoxin Contamination in Groundnuts. In Mycotoxins: Detection Methods, Management, Public Health, and Agricultural Trade, edited by J. F. Leslie and A. Visconti. 
Wallingford, U. K.: CAB International.

Waliyar F, Natre BR, Traore A, Diarra B, Kodio O and Kumar PL (2005).

Pre- and postharvest management of aflatoxin contamination in groundnut. International Crops Research Institute for the Semi-Arid Tropics: Institut d'Economie Rurale (IER), Mali. www.aflatoxin.info. 5/10/2013.

Wu F, Guclu H (2012). Aflatoxin regulations in a network of global maize trade. Plos ONE 7(9):e45151.
Wu F, Khlangwiset P (2010). Health economic impacts and costeffectiveness of aflatoxin reduction strategies in Africa: Case studies in biocontrol and postharvest interventions. Food Addit. Contamin. 27:496-509. 